\title{
BROOD PARASITISM BY INDIAN HAWK-CUCKOO (HIEROCOCCYX VARIUS VAHL.)
}

\author{
G. Prasad ${ }^{1}$, P.O. Nameer ${ }^{1}$ and M.V. Reshmi ${ }^{2}$ \\ ${ }^{1}$ College of Forestry, ${ }^{2}$ College of Horticulture, Kerala Agricultural University, KAU (PO), Thrissur, Kerala 680656, India . \\ Email: gprasadg@rediffmail.com(GP); nameer@vsnl.com (PON)
}

\begin{abstract}
The Indian Hawk-Cuckoo (Hierococcyx varius Vahl.) was found to be a brood parasite on Pale-capped Babbler, Turdoides affinis (Jerdon) in Kerala Agricultural University (KAU) Campus, Thrissur. The chances of babbler nests parasitised by cuckoos is maximum when they build nests on open-crowned and exposed trees at heights more than $5 \mathrm{~m}$. However, the nest building materials and the flock size of the babbler family did not influence the cuckoo in selecting the host. The study also indicates that the cuckoo may be destroying the eggs or the chicks of the host.
\end{abstract}

\section{Keywords}

Hierococcyx varius, Indian Hawk-Cuckoo, parasitism, babblers, Turdoides spp.

\section{Introduction}

In spite of all that has been published by Baker $(1906-07,1908)$ and others, unequivocal data on the breeding of Indian parasitic cuckoo are by and large lacking (Becking, 1981). Most cuckoos are known for their act of brood parasitism, the details of which are still unraveled. Each cuckoo has its own specific host, like babblers, bulbuls, crows, ioras, etc., who act as foster parents to bring up the cuckoo chicks.

The Ceylon Hawk-Cuckoo (Hierococcyx varius ciceliae) changed the host from the Ceylon Babbler (Turdoides rufescens) to the Jungle Babbler (Turdoides striatus) during the course of its habitat change (Lushington, 1949). Macdonald (1959) reported that four Large Grey Babblers (Turdoides malcolmi) constructed the nest jointly, in which two females laid their eggs. Communal defense of the fledglings of the Large Grey Babblers (Turdoides malcolmi) was reported by Dharmakumarsinhji (1961). Jungle Babblers are parasited by other cuckoos also. A Pied Cuckoo (Clamator jacobinus) chick was found to be fed by four Jungle Babblers (Bates, 1938, 1959). Ali (1968) has reported the Brown Dipper (Cinclus pallasii) as a host of a cuckoo (Cuculus sp.).

Brood parasitism in Indian Hawk-Cuckoo (Heirococcyx varius) has been reported by Himmatsinhji (1980) and Ali (1969). Their preferred hosts are babblers; in Kerala the favorite host is the Jungle Babbler (Turdoides striatus) (Ali, 1969).

Mathew et al. (1980) and, Zacharias and Mathew (1988) had done a detailed study on the breeding biology of the babblers. Becking (1981) reported Turdoides affinis, Turdoides striatus, Turdoides rufescens and many species of laughing thrushes as hosts of the Indian Hawk-Cuckoo. Johnsingh et al. (1983) reported that there was no cooperative hunting or food sharing between adult Pale-capped Babblers and that their chief food was animal matter. The egg colour and size of the cuckoo matches exactly that of the babbler eggs. The cuckoos are faster in egg laying and it is believed that the female cuckoo inherits her egg colour exclusively from her maternal parent (Martin, 1987).

The nest owners are said to eject the cuckoo eggs from the nest if the contrast is perceived and the eggs vary considerably (Livesey, 1938). Investigations into the nest building biology of birds include nest lodging sites, nesting height preference, nest construction material, nest composition, nest morphology, colonial nesting and nesting territory (Baker, 1929; Ali \& Ripley, 1987; Hanzak, 1971), which are of practical importance in bird conservation and management (Anon, 1981). This is emphasized by the fact that protecting and promoting the breeding and feeding habitats only can ensure conservation of birds in their natural range.

A brief study was conducted on the breeding biology of Palecapped Babblers and brood-parasitism of the Indian HawkCuckoo in the Kerala Agricultural University campus, Thrissur, Kerala from June 1997 to May 1998. The purpose of the study was to learn

(i) whether the nest location and height, nesting material and flock size of the babblers have any influence on it being parasitised by the Indian Hawk-Cuckoo; and

(ii) whether the cuckoos damage the host's eggs or nestlings.

Manuscript received 9 January 2001; $\quad$ Revised manuscript received 1 May 2001; $\quad$ Accepted for publication 1 June 2001 


\section{Study area and Methods}

The study was conducted at Kerala Agricultural University (KAU) main campus, Vellanikkara, Thrissur District, Kerala covering a total area of $391.44 \mathrm{ha}$. The area lies within a longitude of $76^{\circ} 13^{\prime}$ and latitude of $10^{\circ} 14^{\prime}$. The area consists of plantations of coconut, arecanut, rubber and cocoa. There are gardens, grasslands and natural vegetation of trees and shrubs. Out of the 1,200 species of birds that are reported from India (Ali, 1979), 475 have been reported from Kerala (Neelakantan et al., 1993). The Kerala Agricultural University (KAU) Campus supports about 140 birds. Out of the 15 species of cuckoos in Kerala, nine species are reported from KAU campus (Nameer et al., 2000)

The area enjoys a tropical climate. The Southwest Monsoon contributes a greater proportion of the rain compared to the Northeast. Rainfall is $3042.8 \mathrm{~mm}$. Mean monthly maximum temperature (Mar.-Feb.) is from $28.6^{\circ} \mathrm{C}-35.7^{\circ} \mathrm{C}$ and mean monthly minimum temperature varies from $21.8^{\circ} \mathrm{C}-24.5^{\circ} \mathrm{C}$. Mean monthly maximum humidity varies from $95-77$ per cent.

The study was done from June 1997 to May 1998 in the KAU campus. A thorough search for nests was done during the reported breeding season of Pale-capped Babbler (March to June). A total of nine nests were located in different areas in the campus. Observations such as the species of tree on which the nest was constructed, the height of the nest, distance from human habitation and the flock size of the babbler family were made. The nest building materials were identified after the birds abandoned them. Observations were made for all the nests, the behaviour of birds were also noted, and compared to the nest with cuckoo chick. The fledgling was followed after its emergence from the nest.

\section{Results and Discussions}

Observations on the Pale-capped Babbler nests are given in Table 1.

\section{Nest height}

The two parasitised nests were at a height of $4.8 \mathrm{~m}$ and $5.5 \mathrm{~m}$ from ground level. The other Pale-capped Babbler nests were lower (Mean height $=1.93 \mathrm{~m}, \mathrm{sd}=0.73 \mathrm{~m}, \mathrm{n}=7$ ). We assume that the probability of babbler nests being parasitised by cuckoos is more if the nests are located at a height of more than $5 \mathrm{~m}$.

\section{Host tree}

Two parasitised nests were located on Ailanthus triphysa and Simaruba glauca, both the trees, incidentally, belong to the family Simaroubaceae. These two trees have an open crown and the branches are well exposed. The parasitised nests were more exposed when compared to other nests.

\section{Flock size of babblers}

The flock size of all the nine babbler families varied from four to seven $($ mean $=5.44, \mathrm{sd}=1.13)$. The flock sizes of the cuckoo occupied nests were five and seven. The flock size of the babbler family did not have any effect on it being parasitised by the cuckoo.

\section{Nest building material}

The nesting materials also were more or less the same in all the nests studied. They were mostly composed of Casuarina needles, fine grass and roots. Twines were found to be a common material forming the major part of the nest, second being the roots and grasses. Some nests also had banana fibres in them. The nest building material, we assume, does not have any effect on the nest being attracted or repelled by the cuckoo.

The composition of the nestling(s) and $\operatorname{egg}(\mathrm{s})$ in all the nests studied is given in Table 2.

While more than one chick or egg was observed in the nonparasitised nests, the parasitised nests had only the cuckoo chick. This probably indicates that the cuckoo (either the mother or the chick) may be destroying the eggs or the chicks of the host.

\section{General observations on the babbler nest}

All the members of the babbler flock fed the nestlings or fledgelings. The feeding was more frequent in the morning and

Table 1. Observations on the Pale-capped Babbler nests during 1997-1998 in Kerala Agricultural University campus,Thrissur.

\begin{tabular}{lllll}
\hline Host Tree & Family & $\begin{array}{l}\text { Nest } \\
\text { height }(\mathrm{m})\end{array}$ & $\begin{array}{l}\text { Flock } \\
\text { size }\end{array}$ & Nest building material \\
\hline 1. * Ailanthus triphysa & Simaorubaceae & 5.5 & 5 & Dry grass, Twines, Fine roots, Casuarina needles \\
2. * Simaruba glauca & Simaroubaceae & 4.8 & 7 & Dry grass, Twines, Fine roots, Casuarina needles \\
3. Anacardium occidentale & Anacardiaceae & 1.52 & 5 & Dry grass, Twines, Fine roots, Casuarina needles, Banana fibres \\
4. Anacardium occidentale & Anacardiaceae & 1.64 & 6 & Dry grass, Twines, Fine roots, Casuarina needles \\
5. Caesalpinia corriaria & Leguminaceae & 3.33 & 7 & Dry grass, Twines, Fine roots, Casuarina needles \\
6. Sterculia guttata & Sterculiaceae & 2.54 & 4 & Dry grass, Twines, Fine roots, Casuarina needles \\
7. Mimusops elenjii & Moraceae & 1.46 & 4 & Dry grass, Twines, Fine roots, Casuarina needles \\
8. Musa sp. & Musaceae & 1.54 & 6 & Dry grass, Twines, Fine roots, Casuarina needles, Banana fibres \\
9. Piper nigrum. & Piperaceae & 1.48 & 5 & Dry grass, Twines, Fine roots, Banana fibres
\end{tabular}

* Nests with Indian Hawk-Cuckoo chick. 
Table 2. Composition of the nests of the Pale-capped Babblers.

\begin{tabular}{llll}
\hline Host Tree & $\begin{array}{l}\text { Cuckoo } \\
\text { chick }\end{array}$ & $\begin{array}{l}\text { Babbler } \\
\text { chick }\end{array}$ & $\begin{array}{l}\text { Babbler } \\
\text { eggs }\end{array}$ \\
\hline 1. * Ailanthus triphysa & 1 & 0 & 0 \\
2. * Simaruba glauca & 1 & 0 & 0 \\
3. Anacardium occidentale & 0 & 3 & 0 \\
4. Anacardium occidentale & 0 & 2 & 0 \\
5. Caesalpinia corriaria & 0 & 3 & 1 \\
6. Sterculia guttata & 0 & 2 & 0 \\
7. Mimusops eleniii & 0 & 2 & 1 \\
8. Musa sp. & 0 & 2 & 0 \\
9. Piper nigrum. & 0 & 2 & 1 \\
\hline
\end{tabular}

* Nests with Indian Hawk-Cuckoo chick.

late afternoon hours. During hot noon hours, the birds either fed themselves or took rest in nearby branches. Most of the time one bird kept a watch over the entire area from atop a high branch giving warning signals to intruders. In case of intruders including man, Black-hooded Orioles, domestic cat, crows, mongoose, Asian Koel and squirrels, they made great fuss and managed to keep the intruder away. Johnsingh et al. (1983) reported that Shikra (Accipiter badius) has created the most anti predator responses from the Pale-capped Babblers. In our study, we noticed that one bird spent the night with chick(s) when they were without plumage. But when the chicks developed plumage, they were left alone. Eggs were noticed unhatched in three nests without a cuckoo chick. The nest on the Mimusops elenjii was found destroyed, when the two fledglings started to develop feathers and the egg was seen on the ground attacked by ants.

\section{Observations in nests with cuckoo chicks}

The frequency of feeding the cuckoo nestling was higher, when compared to the feeding frequency to the babbler chicks. After leaving the nest, the cuckoo perched at heights varying from $4 \mathrm{~m}$ to $18 \mathrm{~m}$, in spite of which they were being fed by the babblers. It may be noted that babblers seldom go to that height otherwise. Occasionally, it was observed that the cuckoo fledgling came down to the bushes at a height of $3 \mathrm{~m}$ begging for food but it never came to the ground.

\section{Acknowledgements}

The authors are grateful to Dr. Luckins C. Babu, Associate Dean, College of Forestry, for permitting to undertake the study; Mr. Shyam Parameswaran and Smitha G. Nair, former students of the College of Forestry, are acknowledged for accompanying us in the field.

\section{References}

Ali, R. (1968). The Brown Dipper (Cinclus pallasii) as a host of a cuckoo (Cuculus sp.). Journal of the Bombay Natural History Society 64(3): 561.
Ali, S. (1969). Birds of Kerala. Oxford University Press, New Delhi, 380 pp. Ali, S. (1979). The Book of Indian Birds. BNHS, Oxford University Press, Madras, 354 pp.

Ali, S. and D.S. Ripley (1987). The Compact Edition of the Birds of India and Pakistan. $2^{\text {nd }}$ Ed. Oxford University Press, Mumbai.

Anon (1981). Estimating Wildlife habitat variables. U.S. Fish and Wildlife Service, U.S. Department of Interior, Washington D.C. 20240, 111p.VI 2nd Ed. Taylor and Francis, Red Lion Court, Fleet Street, London, 409 pp.

Baker, E.C.S. (1906-07). Oology of Indian parasitic cuckoos (Part I). Journal of the Bombay Natural History Society 17(1): 72-84.

Baker, E.C.S. (1906-07). Oology of Indian parasitic cuckoos (Part II). Journal of the Bombay Natural History Society 17(2): 351-374

Baker, E.C.S. (1906-07). Oology of Indian parasitic cuckoos (Part III). Journal of the Bombay Natural History Society 17(3): 678-697.

Baker, E.C.S. (1908). Oology of parasitic cuckoos. Journal of the Bombay Natural History Society 18(4): 915-916.

Baker, E.C.S. (1929). The fauna of British India including Ceylon and Burma, Birds, Vol. 1.

Bates, R.S.P. (1938). On the parasitic habits of the Pied-crested Cuckoo (Clamator jacobinus (Bodd.)). Journal of the Bombay Natural History Society 40(1): 125.

Bates, R.S.P. (1959). Communal nest-feeding in Babbler. Journal of the Bombay Natural History Society 56(3): 630-631

Becking (1981). Notes on the breeding of Indian cuckoos. Journal of the Bombay Natural History Society 78(2): 201-231.

Dharmakumarsinhji, (1961). Communal defense of the fledglings of the Large Grey Babblers (T. malcomi (Sykes)). Journal of the Bombay Natural History Society 58: 512.

Hanzak, J. (1971). Birds, Eggs and Nests. The Hamlyn Publishing Groups Ltd., Toronto, 320 pp.

Himmatsinhji, M.K. (1980). The common hawk-cuckoo, Cuculus varius Vahl. in Kutch. Journal of the Bombay Natural History Society 77(2): 329.

Johnsingh, A.J.T., K. Paramanandham and S. Murali (1983). Foraging behaviour and interactions of White Headed Babblers (Turdoides affinis) with other species. Journal of the Bombay Natural History Society 79(3): 503-514.

Livesey, T.R. (1938). Cuckoo problems. Journal of the Bombay Natural History Society 40(2): 329-330.

Lushington, C. (1949). Change in habits of the Ceylon Hawk Cuckoo (Hierococcyx varius ciceliae Phillips). Journal of the Bombay Natural History Society 48(1): 582-584.

Macdonald, M. (1959). Communal nest-feeding in Babblers. Journal of the Bombay Natural History Society 56(1): 132-134.

Martin, P.B. (1987). World Birds 132. 151-152 pp.

Mathew, D.N., T.C. Narendran and V.J. Zacharias (1980). A comparative study of the feeding habits of certain species of Indian birds affecting agriculture. Journal of the Bombay Natural History Society 75(supplement edition): 1187.

Nameer, P.O., R.R. Nair, K.R. Anoop, S.G. Nair, R. Lakshmi and P. Radhakrishnan (2000). Birds of Kerala Agricultural University Campus, Thrissur. Zoos' Print Journal 15(4): 243-246.

Neelakantan, K.K., C. Sasikumar and R. Venugopal (1993). A Book of Kerala Birds. World Wide Fund for Nature - India, Thiruvananthapuram.

Zacharias, V.J. and D.N. Mathew (1988). Ecology of Babblers. Journal of the Bombay Natural History Society 85(1): 50-63. 